https://doi.org/10.52058/2786-4952 -2021-4(4)-151-160

Кобржицький Всеволод В'ячеславович доктор філософії в галузі економіки, професор МКА, професор кафедри менеджменту ННІУЕБ, Міжрегіональна Академія управління персоналом, вул. Фрометівська, 2, м. Київ, 03039, тел.: (044) 490-95-05 (дод. 12-56), e-mail: vsevolodkobr@gmail.com, https://orcid.org/0000-0003-0980-8308

\title{
СТУДЕНТСЬКА ПРАКТИКА У ПІДГОТОВЦІ МАЙБУТНІХ МЕНЕДЖЕРІВ МІЖНАРОДНОГО ТА ВНУТРІШНЬОГО ТУРИЗМУ
}

Анотація. Досліджується проблема використання всіх видів практик для подальшого розвитку загальних $\mathrm{i}$ професійних компетентностей i знань майбутніх менеджерів міжнародного та внутрішнього туризму у вищих навчальних закладах України з метою поліпшення їх володіння знаннями та навичками, необхідними для здійснення туристичного обслуговування вітчизняних і зарубіжних клієнтів.

Українські здобувачі вищої туристичної освіти проходять навчальну, виробничу та переддипломну практики на першому/другому, четвертому курсах бакалаврату та другому курсі магістратури на підприємствах туристичної галузі, переважно підприємствах туристичних операторах.

Показується значення використання для проходження практик підприємств, що надають основні туристичні послуги - закладів громадського харчування, транспортних компаній, готелів і готельних комплексів.

Аналізуються загальні умови проходження практики на діючих вітчизняних підприємствах. Підкреслюється недостатність часу, що виділяється у навчальних планах на проведення студентських практик.

Доводиться першочерговість таких туристських потреб як харчування, надання місця тимчасового проживання, транспортне забезпечення. Формулюється ідея необхідності проведення практик студентів - майбутніх менеджерів міжнародного та внутрішнього туризму на підприємствах, котрі створюють базові послуги для туристів.

Досліджено засади організації практик в ряді зарубіжних країн. Найбільш характерним $\epsilon$ те, що вони переважно досить добре співвідносяться з потребами ринку, і свою практику студенти проходять у багатьох сучасних розвинутих туристичних дестинаціях по всьому світу. Саме тут майбутні туристичні менеджери можуть не лише практично ознайомитись 3 основними принципами функціонування туристичних підприємств, але і здобути знання краєзнавчі, географічні, з маркетингу, економіки, організації та управління, психології.

Підкреслено особливу користь практики в ресторанах і кафе для набуття 
низки необхідних туристичному менеджеру умінь і навичок щодо загальної та професійної культури і безпосередньої роботи з клієнтами.

Ключові слова: студентська практика, навчальна практика, виробнича практика, менеджер міжнародного туризму, туристські потреби, харчування туристів, заклади громадського харчування, практичні навички.

Kobrzhytskyi Vsevolod Vyacheslavovych Doctor of Philosophy in Economics, Professor of International Personnel Academy, Professor of the Department of Management, NNIMEB. Interregional Academy of Personnel Management, Frometivs'ka St., 2, Kyiv, 03039, tel.: (044) 490-95-05 (add. 12-56), e-mail: vsevolodkobr@gmail.com, https://orcid.org/0000-0003-0980-8308

\section{STUDENTS PRACTICE IN TRAINING OF FUTURE INTERNATIONAL AND DOMESTIC TOURISM MANAGERS}

Abstract. The problem of using all types of practices for further development of general and professional competencies and knowledge of future managers of international and domestic tourism in higher educational institutions of Ukraine in order to improve their knowledge and skills necessary for tourism services to domestic and foreign clients.

Ukrainian applicants for higher tourism education undergo training, production and undergraduate internships in the first/second, fourth year of bachelor's and second year of master's degree in enterprises of the tourism industry, mainly in tour operators firms.

The significance of the use of enterprises providing basic tourist services catering enterprises, transport companies, hotels and hotel complexes - for passing practices is shown.

The general conditions of practice at the operating domestic enterprises are analyzed. The lack of time allocated in the curricula for student internships is emphasized.

The priority of such tourist needs as food, provision of temporary residence, transportation is proved. The idea of the need for internships for students - future managers of international and domestic tourism at enterprises that create basic services for tourists is formulated.

The principles of organization of practices in a number of foreign countries are studied. The most characteristic is that they are well correlated with the needs of the market, and students undergo their internship in many modern developed tourist destinations around the world. It is here that future tourism managers can not only get acquainted with the basic principles of operation of tourism enterprises, but also gain knowledge of local lore, geography, marketing, economics, organization and management, psychology.

The special benefit of practice in restaurants and cafes is emphasized for the acquisition of a number of skills and abilities necessary for a travel manager in terms of general and professional culture and direct work with clients. 
Keywords: students practice, educational practice, manager of international tourism, tourist needs, food of tourist, public catering enterprise, practical experience.

Постановка проблеми. Сучасний міжнародний туризм, який ще наприкінці минулого сторіччя трансформувався у багатогранне явище, що поєднує соціальні, економічні, культурні та екологічні аспекти, $є$ цікавим і важливим феноменом. Поєднуючи гуманітарні та економічні сторони життя сучасної людини, він має значний потенціал для подальшого розвитку. Взаємодія 3 багатьма галузями економіки зумовлює його провідне місце у соціальноекономічному житті багатьох країн і народів. Із форми організації дозвілля й відпочинку туризм перетворився на специфічний чинник соціального, економічного, комунікативного та культурного взаємообміну між народами. Зараз туризм став особливим соціальним, економічним, духовним і культурним явищем, що займає помітне місце у людському суспільстві.

Звичайно, значного удару по цій галузі світового господарства нанесено світовою пандемією COVID-19: кількість туристичних подорожей у 2020 p. скоротилась на 74\% в порівнянні з 2019 р. Але, за прогнозами фахівців ЮНВТО [1], до літа 2023 року можна очікувати на повернення усіх показників і здобутків цієї провідної галузі сучасної сфери послуг, яка перед цим забезпечувала роботою понад $8 \%$ усього самодіяльного населення Землі.

Відходять у минуле часи, коли талановиті підприємці, які спирались на власні розуміння, відчуття й досвід, досягали значних успіхів у бізнесі. Сучасність вимагає якісної всебічної підготовки людей, чиї рішення впливають на долі інших шляхом створення робочих місць, а також підтримують розпочату справу, примножуючи здобутки та даючи суспільству ті необхідні продукти, що можуть задовольнити його зростаючий неоднорідний попит. Через це немає потреби доводити, що для успішного виконання своїх функцій менеджер міжнародного та внутрішнього туризму повинен опанувати науку управління, мати відповідну кваліфікацію шляхом засвоєння предметів кожного навчального циклу. Плюс до того - успішне поєднання теоретичної та практичної підготовки 3 напруженою самостійною роботою студента, який хоче стати менеджером.

Помітне місце в підготовці майбутніх фахівців галузей сервісу належить ii практичній частині. Через це від того коли, де і як пройде практика майбутнього туристичного менеджера залежатиме його готовність до успішної самостійної роботи.

Аналіз останніх досліджень і публікацій. Проблеми підготовки сучасних туристичних менеджерів до самостійної роботи розглядалися у працях вітчизняних i зарубіжних учених: Н. Бермана, С. Гадсона, М. Гудіча, О. Ельбрехт, Ю. Лотмана, І. Найдьонова, В. Пазенка, Л. Польової, Т. Ткаченко, В. Федорченка, Ч. Шкрума. Однак поглиблення практичної складової професійної підготовки в літературі майже не висвітлена. 
Журнал«Герспективита інновації науки

(Серія«Гедагогіка», Серія «Геихологія», Серія«Медицин»

№4(4) 2021

Мета статті - дослідження особливостей організації та проведення практичної підготовки майбутнього туристичного менеджера у вищих навчальних закладах 3 метою подальшого активного використання цих умінь i навичок в управлінні підприємством - туристичним оператором або його підрозділом.

Результати дослідження. Сучасна Україна від початку 90-х років XX ст. почала брати участь у світових туристичних процесах. Ми вступили до Всесвітньої туристичної організації, створили та розвиваємо свою туристичну нормативно-правову базу. Відтоді наші співвітчизники стали активно їздити до інших країн світу із різноманітними туристичними цілями, і ми радо та з кожним роком все більше іноземних гостей приймаємо на своїй землі [2. С.31]. Для того, щоб менеджери туристичних підприємств могли добре працювати 3 вітчизняними та зарубіжними туристами, вони повинні мати належні теоретичні знання та практичні навички.

Українські студенти, які навчаються на першому та другому освітніх рівнях бакалавра та магістра проходять практику на підприємствах туристичної галузі. Навчальну - на першому чи другому курсі бакалаврату, виробничу - на четвертому, а магістранти проходять переддипломну на другому році навчання. Зазвичай, практика організовується так, що студенти беруть участь у роботі туристичних підприємств (операторів або агентів) і там опановують секрети, 3 якими підприємства «дозволяють собі» їх познайомити. Як показує досвід, навіть на тих туристичних підприємствах, куди приймають студентів на практику, працівники не поспішають розкривати перед практикантами свої секрети. Особливо це стосується економічних аспектів роботи туроператора чи турагента. Найбільш закритою найчастіше буває робота бухгалтерії, включаючи розрахунки 3 партнерами, нарахування заробітної платні, валютні операції тощо.

У той же час, студенти практично засвоюють порядок роботи з туристичною документацією, здобувають навички комплектування туристичного продукту та розрахунку його ціни, спілкуються з клієнтами турфірми та іiі контрагентами, працівниками консульських установ тощо. Це, звичайно, добре. Але тривалість таких практик незначна: від двох до чотирьох тижнів. I цього часу недостатньо!

Звернувши увагу на сутність сучасного туристичного продукту, можна побачити, що він є комплексом, утвореним низкою корисних для мандрівника послуг та, інколи, товарів туристичного призначення. Але ці важливі й необхідні туристу послуги є дуже різними. В першу чергу, людині, яка вирушила в подорож поза межі свого населеного пункту терміном понад 24 години, потрібно забезпечити дах над головою. Також у першу чергу мандрівника слід нагодувати. Звичайно, він може захопити з собою з дому якийсь сухий пайок, але це годиться для туристських походів, а не для сучасних подорожей, коли можна забезпечити туристу нормальне харчування. I ще в першу чергу мандрівника потрібно забезпечити засобами пересування, тобто транспортом.

Немає жодної помилки в тому, що ці три потреби показані як першочергові. 
Воно насправді є саме так, бо неможливо організувати туристичну подорож без задоволення цих трьох потреб людини. Безумовно, якщо поїздка в цілому нетривала, а пересування між кількома пунктами призначення відповідно до програми можуть здійснюватися вночі, у цьому разі можна спроєктувати тур таким чином, щоб саме такі переїзди забезпечили ночівлі туристам на маршруті.

У контексті цього слід згадати варіант, коли мандрівка здійснюється на власному транспорті. В цьому випадку відпаде першочергова необхідність транспортного забезпечення туру. Проте, такі варіанти реалізуються відносно рідко, особливо для подорожей у віддалені країни.

Аналогічним чином можна знайти ті випадки, коли туристи iз різних міркувань можуть не погодитись на організоване харчування, а віддати перевагу самостійним пошукам закладів громадського харчування. Подібні випадки також нечасті та мають місце тоді, коли турист уже знає країну чи регіон своєї подорожі й має чітке уявлення що, де й коли шукати для власного харчування. Проте, подібне трапляється рідко, а досвідчені туристи добре знають, що сніданок є для них вкрай бажаним і необхідним, а вже пізніше впродовж дня вони собі знайдуть де i що поїсти в залежності від програми туристичної подорожі. Особливу увагу слід приділяти сервісу сніданку, бо із нього починається день споживачів і від його організації багато в чому залежать їх самопочуття та настрій на цілий день.

Слід також зауважити, що особливістю підприємств ресторанного сервісу, котрі обслуговують туристів, є те, що вони повинні задовольняти потреби в харчуванні людей з різних країн світу з їх смаками та традиціями національної кухні. Фахівці громадського харчування вважають, що традиції харчування належать до найбільш консервативних, бо вони формуються упродовж тривалого часу під впливом природних, географічних, соціально-економічних та інших чинників.

Якщо звернути увагу на організацію студентської практики за кордоном, то можна побачити різні i варіанти. Спостерігаються тісний зв'язок навчання 3 виробничою практикою, навчання на робочому місці, взаємозв'язок теоретичних курсів із практичними предметами, тривале стажування на робочих місцях під час навчання у ВНЗ, що сприяє формуванню висококваліфікованих фахівців туризму.

Найбільш характерним $\epsilon$ те, що вони переважно досить добре співвідноситися з потребами ринку, і свою практику студенти проходять у багатьох сучасних розвинутих туристичних дестинаціях по всьому світу. Саме тут майбутні туристичні менеджери можуть не лише практично ознайомитись 3 основними принципами функціонування туристичних підприємств, але i здобути знання краєзнавчі, географічні, з маркетингу, економіки, організації та управління, психології. Здобувачі вищої туристичної освіти набувають практичних навичок, створюючи маркетингові стратегії, готуючи тренування на місцевості, беручи участь в туристичних ярмарках та організовують галузеві зустрічі [3. С.173]. 
Журнал«Герспективита інновації науки

(Серія «Гедагогіка», Серія «Гтихологія», Серія «Медицина»

№4(4) 2021

Такий підхід до організації студентської практики характерний для багатьох європейських країн, де для майбутніх менеджерів міжнародного туризму створено умови для проходження практик не лише у країні, де вони навчаються, а й по всьому світу [4, С.126].

Що стосується американських та канадських вищих шкіл, то вони зосереджують увагу на сучасних методах i формах організації праці в туристичних, готельних і суміжних їм підприємствах (переважно малих i середніх). Північноамериканські педагоги активно працюють над формуванням у майбутніх туристичних менеджерів професійної культури щодо прийняття управлінських рішень під час виконання конкретних робочих завдань у реальних умовах діючого підприємства. Значну увагу вони приділяють i вихованню потреби у постійному поглибленні знань шляхом їх систематичного оновлення 3 подальшим творчим використанням у практичній діяльності. При цьому особливого значення набуває здобута у процесі навчання теоретична основа знань, професійних умінь і навичок майбутніх фахівців. Тобто, спостерігається реалізація особливо важливого принципу тісного взаємозв'язку теорії та практики, що сприяє покрашенню підготовки майбутніх менеджерів 3 туризму [5].

Таким чином, у ряді країн, що по обслуговуванню іноземних туристів займають провідні позиції в світі, навчання майбутніх фахівців галузі базується на двох потужних джерелах знань, умінь і навичок - аудиторних (лекційних i семінарських та практичних) заняттях і різних видах практик. Останні органічно доповнюють перші та дозволяють студентам виробити професійні вміння, що спираються на знання та необхідні якості менеджерів. При проходженні різних видів практик студенти опановують не лише основи майбутньої професії, але й мають змогу шліфувати свої уміння в роботі з людьми, задовольняючи їх потреби, навчаючись спілкуванню з клієнтами і колегами.

Цей аспект усієї практичної діяльності туристичного менеджера особливо важливий через те, що саме уміння спілкуватись (слухати та доносити до співрозмовника свої думки, вислуховувати опонента й уміти його переконати тощо) є вирішальними у досягненні професійного успіху такого фахівця. Чому на цьому слід наголосити?

Відомо, що робота керівника сфери матеріального виробництва та управлінця сфери послуг мають істотні відмінності. Їх можна визначити як необхідність особливої адаптивності менеджера сфери послуг до швидкоплинних вимог ринку, потреба постійної тісної взаємодії з клієнтами та партнерами фірми, миттєву реакцію на найменші зміни їх смаку і попиту. Саме тому менеджер сфери послуг, особливо туризму, повинен [6, С.42]:

- добре розуміти галузевої і місцевий ринки;

- володіти основами психології;

- вільно володіти державною та хоча б однією іноземною мовою;

- володіти мистецтвом переконання. 
Немає потреби доводити, що робота 3 прийому та обслуговування іноземних і вітчизняних гостей не тільки вкрай відповідальна, але й цікава та важлива. При цьому слід наголосити, що людина, яка приїздить до іноземної країни чи навіть іншого регіону своєї власної, потребує додаткової уваги та опіки з боку господарів, які їі тут приймають. В цьому контексті доречно згадати відому теорію потреб Абрагама Маслоу, згідно 3 якою на першому місці у людини знаходяться фізіологічні потреби. I хоча нерідко їх задоволення може йти не згідно 3 відомим алгоритмом «від нижчих рівнів до вищих», а 3 «перестрибом» через сходинку, для людини в чужому середовищі забезпечення саме базових, фізіологічних потреб $\epsilon$ особливо важливим, а не тільки першочерговим.

Серед великого комплексу основних і супутніх туристичних послуг, що можуть бути запропоновані сучасному пілігримові, щонайменше дві знаходяться на нижньому рівні ієрархії потреб Маслоу. Це потреби в їжі й напоях та потреба у забезпеченні ночівлі в чужому для туриста місці. Тому початкове знайомство із усім різноманіттям туристичного обслуговування доцільно починати iз громадського харчування, що є дещо простішим, ніж послуги гостинності.

До важливих характеристик послуг, що забезпечують їх здатність задовольняти відповідні потреби клієнтів, відносяться серед інших: комунікативність і уважне ставлення. У цьому випадку під комунікативністю розуміють здатність забезпечити таке обслуговування, котре виключить непорозуміння між персоналом i клієнтами завдяки тому, що необхідна інформація буде надаватися клієнтам вчасно і без додаткового прохання 3 їхнього боку. А під уважним ставленням розуміють індивідуальне обслуговування та уважність, які підприємство виявляє до клієнта. Особлива цінність цієї характеристики послуги пояснюється тим, що кожен клієнт має особисті потреби, які відрізняються від потреб інших людей. Надаючи послуги, слід показувати, що конкретний клієнт є для закладу особливим, що його індивідуальні потреби будуть враховані.

Досвід показує, що під час туристичних подорожей людина, поряд iз основними послугами закладів харчування, значно охочіше користується й додатковими та супутніми. До них відносяться вар'єте, оркестр, музичний супровід без оркестру, телевізор (за бажанням клієнтів), танцювальний майданчик, можливість замовити таксі, купити сувеніри чи квіти тощо.

Сьогодні їжа є не лише звичною потребою кожної людини. Сучасні туристи розглядають ii також як розвагу i задоволення. Їжа різних народів i навіть регіонів може бути дуже своєрідною, тому привабливою для мандрівників. До того ж, добре почастувати гостя - традиція ледь не всіх народів. Для багатьох туристів знайомство 3 національною кухнею є цікавим і важливим елементом програми туру.

Великою популярністю серед туристів користуються етнографічні бари, ресторани та кафе. Там національні особливості виявляються в інтер'єрі, одязі 
Журнал«Герспективитаінновації науки»

(Серія«Гедагогіка», Серія«Гцихологія», Серія«Медицинв»

№4(4) 2021

обслуговуючого персоналу, репертуарі оркестру та розважальних програм. загальній композиції сервірування столу, підборі посуду та столових приладів, кольоровій гамі чи візерунках скатертин і серветок, асортименті пропонованих страв і напоїв.

Мандрівник забезпечується їжею та напоями не лише в місцях перебування, a нерідко і під час переїздів, де саме якість обслуговування робить таке харчування можливим.

Сучасний туризм - типовий представник великої й різноманітної сфери послуг. Практично всі знання теоретичного характеру та практичні навички, корисні для менеджера з туризму, можуть бути з успіхом використані у будьякому іншому виді сфери послуг. Тут $є$ і зворотний зв'язок. Так, пізнання азів професії туристичного менеджера пролягає через знайомство 3 роботою ресторану чи кафе.

Якщо розглянути не безпосереднє обслуговування клієнтів, а фрагмент підготовчої роботи офіціанта ресторану, то він повинен уміти прикрасити стіл. Для цього можна використовувати свіжі квіти - садові, польові, окрім квітів із різким або терпким запахом. Для створення композицій використовуються різні аксесуари: вази та інші ємності (глечики, плетені кошички тощо), каркаси 3 дроту, дротяні сітки, скляні кульки тощо. Квіти можна просто ставити у вази, заповнені свіжою водою. Для обслуговування урочистих обідів, сніданків, вечерь створюють складні композиції.

Хіба такі навички не будуть корисними для того аби створити приємну затишну комфортну естетичну атмосферу в офісі туристичної фірми? I самим працівникам, i клієнтам це однозначно сподобається i матиме певний психологічний вплив на їх вибір подорожі саме в цій турфірмі.

Для багатьох людей робота у сфері громадського харчування видається простішою та зрозумілішою через те, що із багатьма операціями та процедурами вони давно, а нерідко й добре знайомі. Молоді люди практично без досвіду можуть без надмірних зусиль швидко опанувати простіші професії ресторанного бізнесу та поступово познайомитися і з тими з них, що є складнішими.

Не буде перебільшенням стверджувати, що студент практикант, може ледь не на кожному робочому місці (звичайно, крім кухні, та керівних посад закладу харчування, де без професійної підготовки йому робити нічого) виконувати певні виробничі завдання. При цьому в процесі спілкування 3 клієнтами закладу, колегами та керівниками практикант-студент здобуває безцінний досвід комунікацій з різними групами людей, навчається розуміти їх та формулювати й висловлювати свої думки щодо конкретних виробничих і життєвих ситуацій. Практикант не тільки знайомиться із нормальними проханнями чи вимогами інших людей, але і з їх можливими капризами та забаганками, вчиться та звикає спокійно й адекватно реагувати та знаходити позитивні рішення у складних ситуаціях.

Спостерігаючи за роботою метрдотеля чи адміністратора, студент 
практикант вчиться бути не лише ввічливим, але й уважним та завбачливим 3 одночасним збереженням почуття гідності.

Спираючись на власні спостереження, можна стверджувати, що ті студенти, які працюють у ресторанах, кафе чи інших закладах громадського харчування, значно активніше працюють на семінарських і практичних заняттях, знаходять такі рішення навчальних завдань і задач, які не завжди можуть запропонувати навіть більш сильні студенти, які не працюють у сфері послуг. Очевидно, має місце проекція власного досвіду контактування з клієнтами на роботі на ті учбові завдання, що їх отримують такі студенти. Адже наявність можливості спілкування на роботі з різними людьми, які мають і потреби, і побажання, i нерідко просто якісь капризи, виробляє у працюючого студента певний комплекс комунікаційних навичок і загострює його увагу до звернень відвідувачів, формує правильний підхід до самого процесу обслуговування клієнтів, що так важливо для успішної роботи у сфері послуг взагалі та в туризмі зокрема.

Якщо призвичаювати майбутніх туристичних менеджерів до активної роботи із споживачами під час проведення практик, що передбачені навчальним програмами та навчальними планами підготовки фахівців відповідних спеціальностей, то починати слід із громадського харчування, до якого новачкові сфери послуг не складно адаптуватися.

Робота 3 потенційним клієнтом туристичної фірми вимагає не тільки хорошого знання своїх турпродуктів, загальної ситуації на ринку туристичних послуг та конкретно - ринку свого міста. Вона ставить задачу перед туристичним менеджером розібратися 3 усіма побажаннями й забаганками та перетворити потенційного клієнта на реального. Тут знадобляться не лише професійні знання, а й ввічливість, витримка, уважність та багато іншого, що можна назвати культурою обслуговування.

Перш ніж прийняти замовлення до виконання, менеджер туристичної фірми має пересвідчитись що він точно й однозначно зрозумів вибір клієнта, який у свою чергу цілком однозначно зрозумів менеджера. Знову пряма аналогія 3 ресторанним обслуговуванням. Пошук та підбір варіантів може бути непростим через різні обставини, що не залежать він туристичного менеджера, але від нього залежить наскільки швидко й точно це буде зроблено. Time is money! I не лише для менеджера, а й для клієнта, а тому його слід берегти.

Висновки. При проходженні практики студенти мають особливу нагоду здобути неоціненний досвід практичної діяльності у своїй майбутній професії. Оскільки туристичні послуги складаються 3 певного набору корисних для мандрівників послуг, майбутні менеджери з туризму повинні добре розуміти їх сутність та уміти надавати такі послуги своїм клієнтам.

Майбутні фахівці галузі у процесі навчання у вищій школі повинні пройти практики на підприємствах, що надають основні турпослуги. Доцільно починати iз закладів громадського харчування, переходячи в подальшому до практик в готельних і туроператорських підприємствах. 
Не дивлячись на різні когнітивні здібності здобувачів вищої освіти, їх поступове уведення в реальний світ туризму шляхом проведення практик дозволить виробити необхідні для роботи у цій галузі навички, що в поєднанні із знанням теорії сприятиме появі нових хороших фахівців менеджерів 3 міжнародного та внутрішнього туризму.

\section{Jimepamypa:}

1. https://www.e-unwto.org/loi/wtobarometereng

2. Kobrzhytsky V. Some Aspects of the Development of Tourism in Ukraine // The Ukrainian Review. - 1998. - vol. 45. - No. 1 - P. 29-33.

3. Кобржицький В. В. Особливості підготовки майбутніх менеджерів міжнародного туризму в сусідніх з Україною країнах СС // Сучасні аспекти модернізації науки в Україні: стан, проблеми, тенденції розвитку: матеріали IV Міжнародної науково-практичної конференції, м. Київ; Мадрид, 07 грудня 2020 р. / за ред. С.О. Романенка, І.В. Жукової. Київ; Мадрид: ФОП КАНДИБА Т. П., 2020. 198 с. С. 171-175.

4. Hudson S. An International Handbook of Tourism Education / S. Hudson. - New York: Elsevier Ltd. $-2005 .-238$ p.

5. The Travel Academy. - Режим доступу: http://www.thetravelacademy.com

6. Кобржицький В. В. Комунікаційний менеджмент у підготтовці фахівців міжнародного туроизму та інших галузей сфери послуг // Перспективи та інновації науки (Серія «Педагогіка», Серія «Психологія», Серія «Медицина»): журнал. 2021. № 1(1) 2021. С. 113. C.39-48 DOI: https://doi.org/10.52058/2786-4952-2021-1(1).

\section{References:}

1. https://www.e-unwto.org/loi/wtobarometereng

2. Kobrzhytsky V. Some Aspects of the Development of Tourism in Ukraine // The Ukrainian Review. - 1998. - vol. 45. - No. 1 - P. 29-33.

3. Kobrzhytsky V. V. Peculiarities of training future managers of international tourism in the EU countries neighboring Ukraine // Modern aspects of modernization of science in Ukraine: conditions, problems, development trends: materials of the IV International scientific-practical conference, Kyiv; Madrid, December 7, 2020 / ed. Y.O. Romanenko, I.V Zhukova. Kyiv; Madrid: FOP CANDYBA T. P., 2020. 198 p. Pp. 171-175 [in Ukrainian].

4. Hudson S. An International Handbook of Tourism Education / S. Hudson. - New York: Elsevier Ltd. - 2005. - 238 p.

5. The Travel Academy. - Режим доступу: http://www.thetravelacademy.com

6. Kobrzhytsky V. V. Communication management in training of specialists of international tourism and other branches of services // Perspectives and innovations of science (Series "Pedagogy", Series "Psychology", Series "Medicine"): magazine. 2021. № 1(1) 2021. P. 113. P.39-48. DOI: https://doi.org/10.52058/2786-4952-2021-1(1) [in Ukrainian]. 